\title{
Innvandrerne er ikke en homogen gruppe
}

\author{
I minoritetshelsestudier slår man ofte sammen flere innvandrerbefolkninger og presenterer \\ dem som én homogen gruppe. Det er lite heldig med slike unyanserte klassifiseringer.
}

I helseforskningen blir innvandrere med forskjellig bakgrunn ofte slått sammen og presentert som én homogen gruppe. Til tross for sterk kritikk av en rekke slike innvandrerhelsestudier utført i USA og England de siste tre tiår $(1,2)$ har man også i en rekke nyere studier her i landet koblet sammen og fremstilt innvandrerbefolkningene som én homogen befolkningsgruppe (3-5). I mange vitenskapelige artikler er innvandrere blitt klassifisert på bakgrunn av geografiske/økonomiske regioner som Sørøst-Asia, Øst-Europa eller Sub-Sahara. Kategorier som «vestlig» og «ikke-vestlig» eller «fra høyinntektsland» versus «fra lavinntektsland» er andre vanlige måter å klassifisere innvandrerbefolkninger på. I disse kategoriene blir ulike etniske folkegrupper slått sammen i en «boks» og merket som om det var en homogen befolkningsgruppe (3-5).

\section{Ulik etnisk tilhørighet gir ulik helsestatus}

Problemet er at man på denne måten konstruerer kategorier som ikke finnes - dermed går man glipp av vesentlig informasjon. Etter vår mening må man se på hver enkelt etnisk gruppe separat dersom man skal kunne få reell kunnskap om helseforskjeller norske minoritetsgrupper imellom. Med «etnisk tilhørighet» menes felles opphav, felles språk, levevaner, kultur og reli-

\section{«Likevel blandes innvandrergrupper fremdeles sammen i én «boks»»}

gion. Etnisk tilhørighet inkluderer således både biologiske og miljømessige faktorer, noen ganger i tillegg lik migrasjonshistorie og erfaringer (1). Det har betydning for de ulike innvandrerbefolkningenes helsestatus at de $\mathrm{i}$ utgangspunktet har ulik etnisk og sosioøkonomisk bakgrunn. I tillegg kommer at forhold knyttet til selve migrasjonen, f.eks. årsak, oppholdstid og grad av diskriminering i Norge vil variere mellom gruppene. Og man må ikke glemme at en innvandrer - som alle andre mennesker - er preget av sin individuelle historie.

Alt dette påvirker helse og helseatferd både før og etter migrasjonen, det er doku- mentert på og innenfor etnisk gruppenivå. Etnisitetens betydning er vist ved etnisitetsbaserte studier, f.eks. InnvandrerHUBRO (2001-02) (6) og Statistisk sentralbyrås levekårundersøkelse (7). Disse viste klare forskjeller i helsestatus (morbiditet og risikofaktorer) og sosioøkonomisk status mellom og også innenfor etniske grupper og sterk sammenheng mellom etnisitet og helsestatus.

I studier hvor ulike etniske grupper slås sammen og kategoriseres som én, kan informasjon om ulikhet mellom gruppene når det gjelder helsestatus og risikofaktorer bli tilslørt. Denne konsekvens er blitt omtalt som «black box epidemiology» - årsakssammenhengen bak slike ulikheter forblir ukjent og skjult («black»), men slutningen som trekkes på studiegruppenivå, er at årsaksmekanismene ligger innenfor selve den påviste sammenhengen («box»).

Likevel blandes innvandrergrupper fremdeles sammen i én «boks», til tross for at sterke innvendinger mot en slik homogenitet fremkom allerede tidlig i 1990-årene (8). I tillegg til de vitenskapelige hensyn til reliabilitet og validitet forplikter også etiske og moralske hensyn - f.eks. at det kan bli vanskelig å treffe med målrettede tiltak for utsatte grupper. Det er ingen tvil om at forskning på migrasjon og helse byr på mange utfordringer. Vanlige problemer kan være små populasjoner, lav deltakelse,

språkbarrierer og begrensede ressurser. Men dette kan ikke rettferdiggjøre sammenslåing av svært forskjellige grupper, noe som kan lede til feiltolkninger når det gjelder ulike innvandreres helsestatus.

\section{Tilpasset helsetilbud fordrer presis kunnskap}

Kunnskap om de ulike innvandrerbefolkningenes helse er et viktig verktøy for å tilpasse helsetilbudet til disse gruppene, gi retning til folkehelsestrategier og tiltak og slik redusere ulikhet $i$ helse gjennom forebygging av sykdom og forbedring av helsetilstanden. Men for å kunne gjøre det trenger vi presis kunnskap nettopp om enkeltgrupper og deres helse. Derfor bør de vitenskapelige miljøer forholde seg kritisk til minoritetshelsestudier som er basert på store kategorier innvandrerbefolkninger og ikke la seg blende av slike vitenskapelig ubegrunnede forenklinger og sammenslåinger. De bør også utvikle og anvende forskningsmetoder som får frem mangfold, likheter/ulikheter og faktisk helsestatus hos disse gruppene.

Etter vår mening er det behov for et omfattende forskningsprogram der man legger vekt på helsestatus og helsetjenestebehov hos innvandrerbefolkninger. Det bør være likeverdig deltakelse i forskning, og vi må sikre at innvandrere ikke ekskluderes fra kliniske studier.

\section{Dawit Shawel Abebe}

Ragnhild Storstein Spilker

Karin Harsløf Hjelde

karinh.hjelde@nakmi.no

Nasjonal kompetanseenhet for minoritetshelse (NAKMI)

Oslo universitetssykehus, Ullevål

0410 Oslo

\section{Litteratur}

1. Nazroo JY. Migration and ethnic differences in health. Ethncity, class and health. London: Policy Studies Institute, 2001: 99-109.

2. Bhopal RS. Research on and with ethnic minority groups: past and future. Ethnicity, race, and health in multicultural societies: foundations for better epidemology, public health, and health care. Oxford: Oxford University Press, 2007: 243-83.

3. Thapa SB, Dalgard OS, Claussen B et al. Psychological distress among immigrants from high- and low-income countries: findings from the Oslo Health Study. Nord J Psychiatry 2007; 61: 459-65.

4. Dalgard OS, Thapa SB. Immigration, social integration and mental health in Norway, with focus on gender differences. Clin Pract Epidemol Ment Health 2007; 3: 24.

5. Kumar BN, Holmboe-Ottesen G, Lien $\mathrm{N}$ et al. Ethnic differences in body mass index and associated factors of adolescents from minorities in Oslo, Norway: a cross-sectional study. Public Health Nutr 2004; 7: 999-1008.

6. Kumar BN, Meyer HE, Liv Grøtvedt et al. The Oslo Immigrant Health Profile. Oslo: Folkehelseinstituttet, 2008.

7. Blom S. Innvandreres helse $2005 / 2006$. Oslo: Statistisk sentralbyrå, 2008.

8. Skrabanek P. The emptiness of the black box. Epidemiology 1994; 5: 553-5.

Manuskriptet ble mottatt 6.5. 2010 og godkjent 24.6. 2010. Medisinsk redaktør Anne Kveim Lie. 